\title{
Empirical Analysis of Long-run and Short-run Dynamic Effects of Deposit Rate, Inflation Rate and GDP on Bank Deposit: Vector Error Correction Model Approach
}

\author{
Solomon Kebede Menza \\ Economics Department, Wolaita Sodo University, Wolaita Sodo, Ethiopia
}

Email address:

kebedes24@gmail.com

To cite this article:

Solomon Kebede Menza. Empirical Analysis of Long-run and Short-run Dynamic Effects of Deposit Rate, Inflation Rate and GDP on Bank Deposit: Vector Error Correction Model Approach. International Journal of Theoretical and Applied Mathematics.

Vol. 5, No. 6, 2019, pp. 83-93. doi: 10.11648/j.ijtam.20190506.12

Received: August 19, 2019; Accepted: September 26, 2019; Published: November 27, 2019

\begin{abstract}
This paper empirically examines the long-run and short run dynamic effects of deposit rate (r), inflation rate $(\pi)$ and GDP on bank deposit. The study targeted commercial bank of Ethiopia (CBE) because it has been taking a lion's share in terms of deposit amount which in turn plays a vital role in deposit refunding for investors. To show the long-run and short run dynamic effects of $\mathrm{r}, \pi$ and GDP on the deposit amount of CBE we took 30 years data from the year 1988 to 2017 from MOFED, CSA, National bank of Ethiopia and CBE data sets. To achieve the objectives vector error correction model (VECM) was used after checking the possible assumptions of our economic series. The results of ADF test statistics confirms our economic series are stationary at their first difference. This indicates that the variables are integrated of order one, I (1). Johansen's co-integration test suggests one co-integrating relationship between the variables. According to our findings, the coefficient of the error correction term for $\mathrm{CBE}$ deposit is statistically significant, and the speed of convergence to equilibrium of approximately 16 percent. Hence, in the short run, deposits are adjusted by 16 percent of the past year's deviation from equilibrium. The joint effect result indicates that except deposit rate all included variables have no significant short-run effect on deposit amount. More specifically, the result of Johansen normalization restriction shows in the long-run on average inflation rate and GDP have a negative effect on deposit, while deposit rate has a positive effect on the total amount of deposit held by CBE, among other findings. Finally, the government and other concerned bodies should take necessary steps to mobilize deposit in CBE.
\end{abstract}

Keywords: Annual Deposit, Vector Error Correction Model, Commercial Bank of Ethiopia

\section{Introduction}

\subsection{Background of the Study}

The financial sector like insurance companies, banks, micro-finance institutions, saving and credit institutions can play a significant role in the economy of a given nation. As car does not operate with the absence of fuel so does the economy of a given country without financial institutions. This implies that financial institutions are synergies for the economic growth as well as development of a nation. The banking industry accounts for about 82 percent of the total financial sector assets, implying that the financial sector is under developed [1]. Thus, banking sector is the largest component of the financial system, and it plays great role on all aspects of the national economy [2].

Currently banks, insurance companies and micro finance institutions (MFIs) constitute the main financial institutions in Ethiopia. The number of operating banks reached 19 as of June 2017 of which 16 are owned privately. The bank branches reached 2,693, with the private sector accounting for 58.1percent. Consequently, the ratio of bank branches to population was reduced to $33,448.2$, reflecting an improvement in financial services outreach. Total banking system capital reached ETB 31.5 billion, of which private banks accounted for 56.5 percent. The state-owned commercial bank of Ethiopia (CBE) accounted for 34percent of banking system capitalization. Meanwhile, total banking system loan disbursements reached ETB 18.9 billion, of which 55.6percent was by public banks and the remainder by 
private banks. About 99.6percent of the private banks' new loans and 54.5percent of public banks loans went to the private sector. About 99.8percent of outstanding private banks loans were claims on private enterprises. While 58.1 percent of public banks outstanding loans (excluding credit to government and inter-bank lending) were claims on public enterprises, 41.9percent were on private enterprises [1]. In addition, from the total capital invested in the banking sector the share of CBE is 34 percent but the share of 16 private banks where only 56.5 percent. This indicates that the role of government owned bank and his playing field are by far different from private owned banks.

Ethiopian banking sector is small in absolute and relative size, which could be characterized by low loan deposit ratios and, as a result, large shares of assets held in the form of government securities [3]. There is a general view that monopolistic competition among banks in terms of price and investment opportunity. Meaning, Competition in terms of price is relatively weak in the Ethiopian banking industry [4].

Deposit by individuals is a major source to resource mobilization of $\mathrm{CBE}$ in particular and banks in general. Hence, deposits have a strong impact in resource mobilization of commercial Banks. On the basis of resource mobilization purpose CBE serve different types of deposit mobilization strategies. These forms were demand deposit, time deposit, youth deposit, saving deposit, women deposit, and fixed time deposit. As a financial intermediary, CBE can collect a deposit from individuals and lends back to these who need capital for investment [5]. Therefore, banks play an intermediary role by collecting excess money in the form of deposit and provide a loan for those who need finance. However, there have been cases whereby private companies and small-scale firms complaining about lack of loans and credit facilities, particularly those which were not able to present collateral properties [6]. In addition, as of other study Ethiopia's rate of domestic saving has been very low as of the standard of Sub-Saharan countries [7].

\subsection{Statement of the Problem}

According to different studies banks perform various roles in the economy. For instance, they improve the information gap between borrowers and investors by monitoring the latter and ensuring an appropriate use of the depositors' endowment [8]. They provide inter temporal smoothing of risk that cannot be diversified at a given point in a time as well as insurance to depositors against unexpected consumption shocks. Due to the mismatch between the maturity of their assets and liabilities, nevertheless banks are subject to the possibility of runs and systematic risk. Similarly, the role of banking sector in the Ethiopian economy is to revolve deposits from the general public investors on interest bases. This shows that depositors are the major stakeholders of banks in deposit mobilization strategies [9].

Furthermore, banks mobilize, allocate and invest much of society's savings. Households, government and businesses are mainly using banks to save their money to get loan for their project undertakings. In most cases commercial banks hold more assets than any other financial institutions [10]. In nutshell the role of commercial banks are facilitating growth and development in the economy. Savings mobilization becomes the most important strategy for the economy when economic growth is planned within the framework of targets with maximum reliance on internal resources [9]. Roy reflecting the contemporary situation of Ethiopia showed that most of the mega projects, including the Grand Ethiopian Renaissance Dam, are financed by internal resources, deposit is now much more significant than ever in Ethiopia.

On the last decades the size of Ethiopian economy has been shown an improvement and accommodating different FDI coupled with the accessibility of banks and banking information systems among dwellers of Ethiopia which have an important impact on the deposit growth of banks. This raises questions on the capacity of commercial banks in enhancing its deposit bases thereby to enhance liquidity services [11]. In addition, IMF and WB strategic process of financial sector liberalization intensified competitions among different commercial banks in Ethiopia by following akin forms of deposit mobilizations.

Examining macroeconomic factors effect on the deposit amount and growth would help policy makers as of in preparing deposit mobilization strategies. Deposit mobilization is the major services of commercial banks. Currently in Ethiopia, the pace of the banking system to mobilize adequate resources would not be sufficient, given the large fund requirement of the economy that would certainly result in liquidity gap. This might be due to the fact that majority of people in Ethiopia are using traditional way of saving, holding money in cash and asset forms particularly in country-sides. Thus, the deposit mobilization practice among commercial banks both government and private owned banks, are not as such accessible at grass root levels [12].

Majority of studies focused from the side of household saving behaviors by giving low attentions for deposit mobilization in banks. Few scholars had conducted an empirical study on factors affecting deposit mobilization in Ethiopia. Accordingly, the major variables that affect deposit of banks include inflation rate, interest rate, exchange rate, demographic change (population growth) and branch expansion, among others. According to other findings branch expansion had positive and significant effect on total deposit whereas deposit interest rate and inflation rate were statistically insignificant affecting deposit [13]. Contrarily branch expansion has negative effect on private saving in the short term. She also concluded that inflation rate influenced private saving negatively and significantly. As per the findings level of real per capital income and urbanization ratio has significant positive effect on private savings [14].

Inflation rate has a negative and insignificant effect, while interest rate had a positive and significant effect on commercial bank deposit [15]. Contrary other study found that inflation rate has a positive and statistically significant effect on bank deposit amount [16]. Even though, the 
direction of the movement between inflation rate and deposit are positive, statistically insignificant according to the study conducted on CBE [17]. Similarly, the effect of interest rate on the total deposit of banks had a mixed result as of the study $[2,13,15,17]$.

The above statements are indicating that majority of scholars had conducted research on deposit mobilization focusing on commercial banks, both private and government jointly to identify factors that affects commercial bank deposits. In addition, majority of the studies conducted in Ethiopia are observing cross sectional data, and some others examined time series data by mixing micro level factors with macro level factors to examine factors that determines bank deposit. Accordingly, there has been inconsistency in their findings. This might be due to their methodological approach, the type of data, and the time span coverage under their study. Hence, this study is conducted to narrow the gap of these controversial results by applying vector error correction model and examining only major macro-level factors, and considering only commercial bank of Ethiopia because of the fact that majority of Ethiopians had an account from this bank. Moreover, the study analyses based on secondary data covering a time span from 1988-2017 for 30 years' annual data.

\subsection{Objectives of the Study}

The general objective of this study is to examine the long-run and short run dynamic effects of deposit rate, inflation rate and GDP on bank deposit of commercial bank of Ethiopia. While the specific objectives of the study are:

1. to identify the existence of long-run dynamics relationship between deposit amount of $\mathrm{CBE}$ and inflation rate, deposit rate, GDP, and their reverse causations.

2. to identify the short run dynamics between deposit amount of $\mathrm{CBE}$ and inflation rate, deposit rate, GDP, and their reverse causations.

3. To identify the speed of adjustment of deposits from their past year dis-equilibrium given the role of GDP, inflation rate and deposit rate.

\section{Theoretical Background of the Study}

\subsection{Theories of the Demand for Money}

In monetary economics, the demand for money arises from the fact that it is an asset for its holders. Since it is acceptable to all, people hold it, not only for making transaction and paying debts, but as a particular form of an asset which is easy to be converted into other goods and services. Thus money is a perfectly liquid asset. Moreover, other assets need to be converted into money to make transactions which involve waste of time, cost and perhaps capital loss. So, there is a demand for money to hold asset in the form of cash and demand deposit. In other hand, the desire to hold financial assets in the form of money is either in the form of cash or bank deposit rather than in the form of investment. But the question raised is that what constitutes the demand for money and why the public demand for money exists given different macroeconomic level variables? To solve such problem the paper reviewed different theories of money demand and setted-out combination of theories.

\subsubsection{Classical Theory of Demand for Money}

This theory is often called as the quantity theory of money which was proposed by Fisher. According to this theory money is not demanded for its own sake, but as a medium of exchange i.e. the demand for money is essentially to spend or to make transaction and the demand for money is determined by the total quantity of goods and service to be transacted during a given period. Again the total demand for money depends on its velocity of circulation as shown in the following equation:

$$
\mathrm{M} * \mathrm{~V}=\mathrm{P} * \mathrm{~T}
$$

Where, T represents the total number of transactions during some period of time, say, a year. In other words, it is the number of times in a year that goods or services are exchanged for money. $\mathrm{P}$ is the price of goods and services transacted. Hence $\mathrm{P} * \mathrm{~T}$ stands for the number of dollars exchanged in a year. Similarly, $\mathrm{M}$ is the quantity of money and $\mathrm{V}$ is the transaction velocity of money, which measures the rate at which money circulates in the economy. Hence MV shows the money used to make the transactions.

\subsubsection{Neo-classical Theory of Demand for Money}

Classical theory of demand for money emphasized on the medium of exchange function of money; the Neo-classical approach is based on the store of value of function of money. According to this approach people want to hold money for various motives, which is influenced by the factor like:

1. Transaction motive

2. Precautionary motive

3. Income and wealth of the individual

4. The opportunity cost of holding money as compared to other assets

5. Habits of the individual, system of payment prevailing in the country

In equation 1 it is difficult to measure the number of transactions in the economy, hence we switch our analyses from transaction to income as transaction is related with aggregate income (output) in the economy. Hence, Y shows the more transaction mean the more goods and services bought and sold. Thus Y stands for the total amount of output in the economy and $\mathrm{P}$ stands for the price of a unit of output, showing that how the nominal output responds for money demand. In other hand, PY is the nominal GDP. Now the quantity equation becomes,

$$
M \times V=P \times Y
$$

Since $\mathrm{Y}$ is the total income, $\mathrm{V}$ is here stands for income velocity of money, which tells us the number of times a dollar bill enters someone's income in a given period of time. 
By rearranging the above equation we have

$$
M=\frac{P Y}{V}
$$

This shows that money demand is proportional to nominal income since $\mathrm{V}$ is constant, and interest rate has no effect on the demand for money. Hence, this theory indicates that people hold money only for transaction purposes.

However, both the classical and Neo-classical theory of money demand are criticized for the following basic points as of different empirical findings:

i. The velocity of the demand for money is not constant

ii. Demand for money is responsive to changes in interest rates

\subsubsection{Keynes's Theory of Demand for Money}

The theory developed by John Maynard Keynes was some times referred as liquidity preference theory and its basic premises is rejecting the notion that velocity is constant over time. A part from transaction and precaution demand for money Keynes's recognizes that people can hold money for another motive. According to him there are three motives for the demand for money: Transaction motive, precaution motive and speculative motive. The demand for money for the first two motives constitutes active cash balance and the demand for money for speculative motive is called idle cash balance.

Money is the medium of exchange, primary demand for money arises for making daily transactions in life, the individual or business income and expenditure are not perfectly synchronized or they do not occur at the same time. People receive income in periods that don't correspond to the times they want to spend it. Generally income is received at a discrete interval, for example, once in 15 days or once in a month but expenditures are more or less continuous, so as to care out the frequent transaction people therefore need to hold a certain amount of money. Thus, the transaction motive refers to the demand for money for bridging the gap between period of receipts and payments.

Given society's basic institutional and technological customs and practices which govern the receipt of income and the flow of expenditure, the transaction demand for money depends upon his personal income and business turn over. The transaction demand, thus, various in direct proportion in money income. The higher the level of money income, the greater the demand for money to make transaction and vice versa. Symbolically, the transaction demand for money can be stated as:

$$
\mathrm{L}_{\mathrm{t}}=\mathrm{K}_{\mathrm{t}}(\mathrm{V})
$$

where Lt represents the transaction demand for money, $\mathrm{K}_{\mathrm{t}}$ represents the fraction of money income society desired to hold as money in the form of cash, because its income and expenditure are not synchronized, and Y represents money income. The transaction demand for money is assumed to be a constant and stable function of income because the proportion of income to be kept for transaction purposes is influenced by the institutional and technological arrangements influencing the payment and receipt of money and these arrangement is do not change in the short run. Hence, the value of $\mathrm{Kt}$ is assumed to be constant.

According to Keynes's, the precautionary demand for money, like the transaction demand, is also constant function of the level of money income, and is insensitive to the change in the interest rate.

Since both the transaction and precautionary demand for money are fairly stable and constant functions of income and both are interest inelastic, Keynes adds them together. The combined sum of money balances held under the transactions and precautionary motives is referred to as "active balances" by Keynes. Thus the demand for active balances is constant function of income.

\subsubsection{Combinations of Theories for Money Demand}

In general the researcher adopts the basic relationship between the demand for money either holding in cash form or deposit as the function of macro-level variables like nominal GDP, the rate of inflation (as implicitly having prices), deposit rate or interest rates depending on the above theoretical bases.

$$
\mathrm{M}^{\mathrm{d}}=\mathrm{f}(\mathrm{GDP}, \mathrm{r}, \pi)
$$

Where, $\mathrm{M}^{\mathrm{d}}$ stands for the proportion of money demand in the form of cash and deposit (time and demand deposit), GDP stands for the total monetary value of production in the given fiscal year, $r$ stands for the deposit(interest) rate of banks, $\pi$ stands for inflation rate of the economy.

Assuming that the market for money clears, the supply for money is equal with money demand, thus at a given fiscal year when the central bank changes its money supply this in turn causes a proportionate change in nominal GDP as of assuming velocity is stable over short period of time (say a given fiscal year). consequently a change in GDP can cause a change in general price level. Hence the quantity theory tells us the price level is proportional to money supply and thereby money demand. In other hand, since the percentage change in the price level is what we call inflation rate $(\pi)$.

By adding percent change in both sides of equation (2):

$$
\% \Delta M \times \% \Delta V=\% \Delta P \times \% \Delta Y
$$

From the above equation, first the percentage change in quantity of money is decided by the central bank. Next, in short run velocity is constant, and consequently the percentage change in velocity becomes zero. Third the percentage change in price is the rate of inflation, which is one of our target variable affecting money demand in the form of deposits. Lastly, the percentage change in output, what we call it as our GDP which also affects deposit level. According to our money demand function (equation7) deposit (interest) rate determines the amount of money demand and simultaneously determines the total amount of deposits. Due to the fact that deposit rate is the cost of holding cash money balances on the hands of the public. Thus theoretical deposit rate and demand for money in the form of cash are inversely related. In other hand, deposit 
rate is positively related with demand for money in the form of deposits. In genera, 1 the researcher was interested to examine whether the findings of this study are supplementing or rejecting or modifying the existing theories relating these major macroeconomic variables, money demand in the form of deposits, GDP, interest rate, inflation, via short run and long run periods.

\section{Methodology of the Study}

\subsection{Research Design}

To examine the linkage of deposit amount of CBE with respect to different macro-level variables, the researcher used quantitative research design by examining a time series data for about 30years.

\subsection{Data Source, Type and Method of Data Collection}

This study used secondary data collected from different organizations like National Bank of Ethiopia, CBE, MoFED and CSA data sets. The target population under review of secondary data macroeconomic factor related with bank deposit over the period covering from 1988 to 2017 as of annual data. The macro level variables, deposit amount, deposit rate, inflation rate, and GDP, are compiled from the data base of different organizations like National Bank of Ethiopia (NBE), Ministry of Finance and Economic Development (MOFED), Central Statistics Authority (CSA) and CBE.

\subsection{Method of Data Analysis}

The study used both descriptive and empirical methods of analysis by using Stata 14 version. The yearly data of deposit amount, and GDP are transformed into natural logarithms form and the rest are taking their actually yearly data as it is in a linear form.

The economic series data was checked for the existence of stationarity of the variables at level form by using Augmented Dickey Fuller (ADF) test to use least square estimation technique of vector autoregressive (VAR) model. However, the result of unit test shows that all variables are not stationary at level form, hence we checked stationarity of the variables at first difference, $\mathrm{I}_{(1)}$. If the data are stationary at first difference, then we proceed with co-integration test. Co-integration is a necessary condition for the existence of a long run equilibrium relationship between variables having unit roots. In testing for co-integration, we have chosen the Johansen Maximum Likelihood method, for which optimal lag order is selected by employing Akaike Information Criterion (AIC), Hannan-Quinn Information Criterion (HQ), Final Prediction Error (FPE), and Schwarz Information
Criterion (SC). The test procedure for ADF test is applied on the following model:

$$
\Delta Y_{t}=\alpha+\beta_{t}+\partial Y_{t-1}+\gamma_{1} \Delta Y_{t-1}+\ldots+\gamma_{\rho-1}
$$

The unit root test is then conducted with the null hypothesis $\left(\mathrm{H}_{0}\right)$ of $\partial=0$ against the alternative hypothesis $\left(\mathrm{H}_{1}\right)$ of $\partial<0$.

If we obtain at least one co-integrating relationship among our variables, we can proceed to carry out Vector Error Correction Model (VECM) that pinpoints about the speed of adjustment to long run equilibrium avoiding the spurious regression problem [18]. Diagnostic test have been carried out to the estimated VECM model by employing Jarque-Bera (J-B) test for normally distributed disturbances, Lagrange Multiplier (LM) test for residual auto-correlation, stability conditions of the VEC estimates and White Test with cross products for heteroscedasticity. We can specify the VEC model as follows:

$$
\Delta Y_{t}=\pi Y_{t-k}+\tau_{1} \Delta Y_{t-1}+\tau_{2} \Delta Y_{t-2} \ldots+\tau_{k-1} \Delta Y_{t-k-1}
$$

Where, $\pi=\left(\sum_{i=1}^{k} \beta_{i}\right)-I_{n}$, and $\tau_{i}=\left(\sum_{i=1}^{j} \beta_{i}\right)-I_{n}$

The long-run cointegrating matrix of $\Pi$ determines the number of cointegrating vectors, whereby it guides us whether to use VEC model or not. The cointegration regression only considers the long-run relationship between our economic series, while the vector error correction model is developed to measure any dynamic adjustments between the first differences of economic series. we can define the error correction term as:

$$
\varepsilon_{t}=Y_{t}-\beta X_{t}
$$

Where $\beta$ is the cointegrating coefficient, and $\varepsilon_{t}$ is the error term from the regression of $Y_{t}$ on $X_{t}$. Then the vector Error Correction Model is simply defined as:

$$
\Delta Y_{t}=\alpha \varepsilon_{t-1}+\gamma \Delta X_{t}+U_{t}
$$

Hence, the first difference of $Y_{t}$ can be explained by the lagged $\varepsilon_{\mathrm{t}-1}$ and $\Delta X_{t}$. And $\varepsilon_{\mathrm{t}-1}$ indicates the one period lagged values of the residuals from estimation of equilibrium error term, or in other hand, a disequilibrium error term occurred in the previous period. In addition, it indicates the speed of adjustment towards the long-run values, thereby it offers an added explanatory variable to explain $\Delta Y_{t}$.

It is possible to extend the above single equation vector error correction model to multivariate systems of equations. According to this paper deposit amount, average deposit rate, inflation rate and GDP are our endogenous variables. Thus, the VEC model can be written as:

$$
\begin{aligned}
& \Delta \text { Deposit }_{t}=\beta_{0}+\beta_{1} \Delta \text { Deposit }_{t-1}+\beta_{2} \Delta \text { Deporate }_{t-1}+\beta_{3} \Delta \text { Inflanrate }_{t-1}+\beta_{4} \Delta G D P_{t-1}+U_{1 t} \\
& \Delta \text { Deporate }_{t}=\alpha_{0}+\alpha_{1} \Delta \text { Deposit }_{t-1}+\alpha_{2} \Delta \text { Deporate }_{t-1}+\alpha_{3} \text { Inflanrate }_{t-1}+\alpha_{4} \Delta \text { GDP }_{t-1}+U_{2 t} \\
& \Delta_{\text {Inflanrate }}=\delta_{0}+\delta_{1} \Delta \text { Deposit }_{t-1}+\delta_{2} \Delta \text { Deporate }_{t-1}+\delta_{3} \Delta \text { Inflanrate }_{t-1}+\delta_{4} \Delta G D P_{t-1}+U_{3 t}
\end{aligned}
$$




$$
\Delta G D P_{t}=\gamma_{0}+\gamma_{1} \Delta \text { Deposit }_{t-1}+\gamma_{2} \Delta \text { Deporate }_{t-1}+\gamma_{3} \Delta \text { Inflanrate }_{t-1}+\gamma_{4} \Delta G D P_{t-1}+U_{4 t}
$$

where ECTt-1 is the lagged error correction term leaving from the long-run co-integrating relations between these four variables. Thus, what we are observing is the vector error correction model is basically a VAR model in its first difference form with the addition of a vector of co-integrating residuals.

\section{Results and Discussions}

\subsection{Descriptive Data Analysis}

According to our data set the mean values of deposit, GDP, average deposit rate and inflation rate are 62.027, 63.78333, 6.4 and 9.65 , respectively. The optimum inflation rate is the one which is in between 2 to 3percent when interest rate is assumed to take zero value [19]. Hence, as of Friedman the existing mean value of inflation rate is normal and does not affect the economy adversely as compared to the mean value of deposit (interest) rate. Whereas the minimum values of deposit, GDP, average deposit rate and inflation rate are 3.495, 17.5, 3.5 and -5.75, respectively. In addition, the maximum values of deposit, GDP, average deposit rate and inflation rate are 364, 200.6, 10 and 33.54, respectively (as shown in Table 1).

Table 1. Descriptive statistics of the variables.

\begin{tabular}{lllll}
\hline Variable & Obs & Mean & Std. Dev. & Min \\
\hline Deposit in billions (Birr) & 30 & 62.02673 & 93.57285 & 3.495 \\
Deposit rate & 30 & 6.400333 & 1.61146 & 3.5 \\
Inflation rate & 30 & 9.65577 & 9.356703 & -5.755335 \\
GDP in billions of USD & 30 & 23.03453 & 21.40697 & 10 \\
\hline
\end{tabular}

Source: Own computation via Stata 14, 2018

\subsection{Performance of $C B E$}

CBE plays a catalytic role in the economic progress and development of the country. In terms of technology also it is the first bank in Ethiopia to introduce automated teller machine (ATM) service for local users. As a result, the bank has more than 15.9 million account holders in the year 2016/2017and it takes the lions share as compared to total private banks in the country. It has strong correspondent relationship with more than 50 renowned foreign banks, including the Commerz Bank AG (German banking and financial services), Royal Bank of Canada, City Bank (financial services multinational Citigroup at New York),
HSBC Bank (multinational banking services, head quarter at London, UK) and others. CBE has a SWIFT bilateral arrangement with more than 700 others banks across the world. CBE has also reliable and long-standing relationships with many internationally acclaimed banks throughout the world. As a result, the bank's asset is increasing growing in the past ten years. Large share of deposit of the bank is mainly from privates and individuals. Others like cooperatives, pubic enterprises and agencies, domestic banks and other financial institutions, central and local governments and foreign banks have their own share in total bank deposits. The banks total deposit growth trend since in 1985 is shown in Figure 1 below.

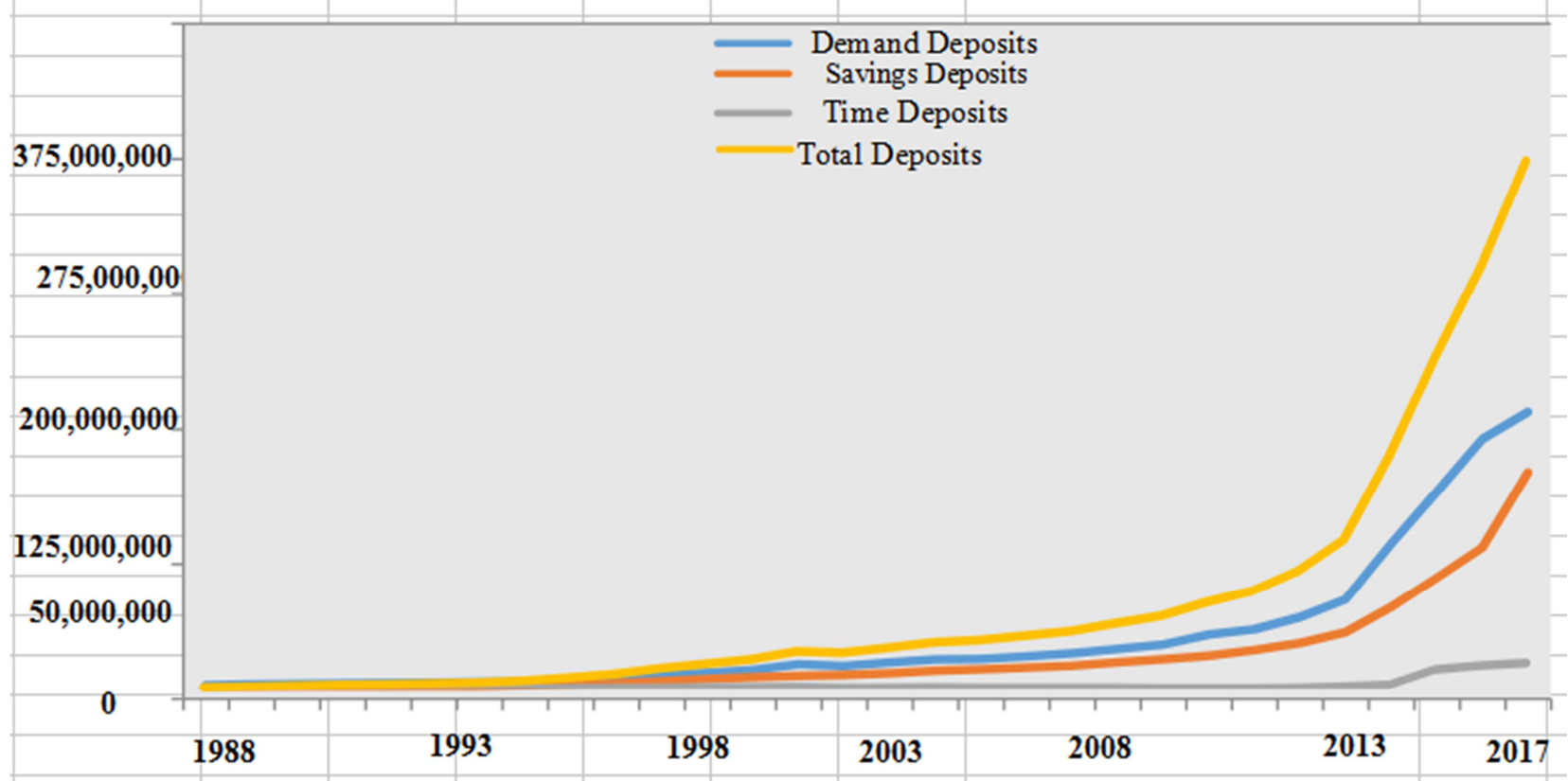

Source: Author's computation, data from CBE

Figure 1. Trends of Deposit Amount by Deposit Type. 
As the figure shows, the demand deposit is much greater than saving and time deposits. The negative real interest rate may compel the depositors to put their money in demand deposit type. All deposit types have been showing a rapid increase in current years particularly since 2010 . The deposit amount of the bank has been steadily growing and it reached 242.497 billion, 288.605billion,364 billion for the year 2015, 2016 and 2017, respectively, and even reached 451 billion for the year 2018. It may be due to rapid expansion of banks branch network over the country, increase of per-capita income of the society thereby a growth in saving amount and rapid economic growth of the country.

\subsection{Econometric Tests and Data Analysis}

\subsubsection{The Unit Root Test}

Table 2 shows the results of augmented dickey fuller (ADF) test statistics by using trend and without trend of variables. As for the analysis of long run relationship between the variables the economic time series must fulfil stationarity assumption. According to ADF result all variables except inflation rate with trend and without trend, are non-stationary at level form. Hence, we fail to reject the null hypothesis of non-stationarity, whereas by taking the first difference of all variables and applying the ADF test with and without trend; the series become stationary as shown below in Table 2. This indicates that the variables are integrated of order one, I (1) and they may exhibit some long run linear combination, and indicating the use of vector error correction (VEC) model provided that co-integration exists among the variables.

Table 2. ADF test for unit root.

\begin{tabular}{llll}
\hline Variables & & At Level & At First difference \\
\hline \multirow{2}{*}{ Total Deposit } & With Trend & -1.088 & $-5.820^{* * *}$ \\
& Without Trend & 1.328 & $-5.490^{* * *}$ \\
Deposit rate & With Trend & -2.585 & $-5.527^{* * *}$ \\
\hline
\end{tabular}

\begin{tabular}{llll}
\hline Variables & & At Level & At First difference \\
\hline \multirow{4}{*}{ Inflation rate } & Without Trend & -2.371 & $-5.639^{* * *}$ \\
\multirow{2}{*}{ GDP } & With Trend & $-3.758^{* *}$ & $-6.906^{* * *}$ \\
& Without Trend & $-3.652^{*}$ & $-7.023^{* * *}$ \\
& With Trend & -1.130 & $-3.573 *$ \\
& Without Trend & 1.725 & $-2.845^{* * *}$ \\
\hline
\end{tabular}

Note: $* * *, * *$, and $*$ are $\mathrm{p}<0.01,0.05$, and 0.1 , respectively. Source: Stata 14 output from annual data set, 2018

\subsubsection{Optimum Lag Length}

To determine the optimum lag length of the economic series we used the FPE, SBIC, AIC and HQIC statistical outputs. Accordingly, the SBIC test indicates the optimum lag length as 1, and FPE test result recommends optimum lag length as 3 years. While AIC and HQIC suggests that the appropriate lag length is four. Thus, the appropriate lag length that is selected in our analysis is four as of most of the criteria recommends (Table 3).

Table 3. Lag Length Selection.

\begin{tabular}{lllll}
\hline Lag & FPE & AIC & HQIC & SBIC \\
\hline 0 & 15.8675 & 14.1156 & 14.1714 & 14.3092 \\
1 & .013715 & 7.04287 & 7.32155 & $8.01063^{*}$ \\
2 & .008663 & 6.48346 & 6.98508 & 8.22544 \\
3 & $.008109^{*}$ & 6.14231 & 6.86688 & 8.6585 \\
4 & .010069 & $5.72811^{*}$ & $6.67563^{*}$ & 9.01851 \\
\hline
\end{tabular}

Note: * lag order selected by the criterion

Source: Stata 14 output from annual data set, 2018

\subsubsection{Identifying the Existence of Co-integration}

To identify the existence of co-integration among the economic series we used one of the log-likelihood ratio tests, i.e. the trace statistics via Johansen tests for co-integration. The test result indicates the existence of one co-integrating vectors which are reported in Table 4 below. The presence of co-integration assures the existence of a stable and long run relationship among variables.

Table 4. Johansen Tests for Cointegration

\begin{tabular}{llllll}
\hline Trend: constant & & Sample: $\mathbf{6}-\mathbf{3 0}$ & & No. ofobs $=\mathbf{2 5}$ & Lags $=\mathbf{4}$ \\
\hline Maximum rank & parms & LL & eigenvalue & trace statistic & 5percent Critical value \\
\hline 0 & 52 & -52.574259 & & 56.9686 & 47.21 \\
1 & 59 & -35.868074 & 0.73723 & $23.5562^{*}$ & 29.68 \\
2 & 64 & -28.87806 & 0.42833 & 9.5762 & 15.41 \\
3 & 67 & -24.772704 & 0.27995 & 1.3655 & 3.76 \\
4 & 68 & -24.089965 & 0.05315 & & \\
\hline
\end{tabular}

Source: Stata 14 output from annual data sets, 2018

\subsection{Vector Error Correction Model Result}

Due to the existence of co-integration among variables we proceed to examine the vector error correction model and the result is displayed below in Table 5. The summary statistics for model adequacy are displayed for each equation in the form of coefficient of determination and the probability values supplementing the adequacy of our specified model.

Table 5. Vector Error Correction Model.

\begin{tabular}{llll}
\hline Sample: $\mathbf{6}$ - 30 & Number of obs $=\mathbf{2 5}$ & \\
\hline & & AIC & $=7.589446$ \\
Log likelihood $=$ & HQIC & $=8.387278$ \\
Det(Sigma_ml $)=$ & -35.86807 & SBIC & $=10.46599$ \\
\hline
\end{tabular}




\begin{tabular}{llllll}
\hline Equation & Parms & RMSE & R-sq & chi2 & P>chi2 \\
\hline D_ddeposit & 14 & .14117 & 0.7393 & 31.19621 & 0.0052 \\
D_ddeporate & 14 & 1.57849 & 0.7606 & 34.95366 & 0.0015 \\
D_dinflanrate & 14 & 8.27037 & 0.9039 & 103.519 & 0.0000 \\
D_dlnGDP & 14 & .105521 & 0.7051 & 26.30286 & 0.0237 \\
\hline
\end{tabular}

Source: Stata 14 output from annual data set, 2018

The VECM allows the long-run behaviour of our endogenous variables to converge to their long-run equilibrium relationship while allowing a wide range of short-run dynamics. The result of error correction model for both short-run and long-run causality are reported in Table 6 . Row 18 in Table 4, 6 shows the error correction term (ECT)) for the equations as logarithm of deposit, inflation rate, deposit rate and logarithm of GDP as equation (1), (2), (3) and equation (4), respectively. Accordingly, the coefficient of the error correction term for deposit variable carries the correct sign and statistically significant at 5percent, with the speed of convergence to equilibrium of approximately 16 percent. Hence, in the short run, deposits are adjusted by 16 percent of the past year's deviation from equilibrium. This confirms the stability of the system. This is consistent with the result that indicates the existence of long-run relationship between deposit and deposit rate in the case of Kenyan commercial bank deposit growth. That finding also supplements long-run relationship between lags of deposit with the total amount of deposit growth [20]. The study conducted in Nigeria assures the existence of long-run relationship running from interest rate, and general price level as rate of inflation to bank deposit amount [21]. Similarly, other finding identified that in the short-run bank deposit is adversely affected by inflation rate [22].

However, the coefficient of the error correction term for deposit rate, inflation rate and GDP is having the expected sign yet statistically insignificant. Hence no need of further interpretation.

Furthermore, the finding shows that there is a short-run unidirectional causality running from the first and second lag of inflation rate and deposit rate, and second lag of logarithm of GDP to total amount of deposit held by CBE. This finding is consistent to the study that examined determinants of Bank deposits in Ghana, which shows that there exists a short-run relationship between inflation rate and deposit [22]. Our study also shows that there is a short-run unidirectional causality running from the third lag of logarithm of deposit to inflation rate. In addition, there exists a short-run unidirectional causality running from the third lag of logarithm of deposit to logarithm of GDP. The result confirms the theory that an increase in inflation rate causes tightening of the monetary policy, which increases the risk-free deposit in banks, this in turn causes a shift from investments in different economic sectors to the safer and less risky savings in a bank. In addition, according to Table 4, 6 , there exists bidirectional causality among inflation rate at $1^{\text {st }}$ and $2^{\text {nd }}$ lag and deposit at $3^{\text {rd }}$ lag. Similarly, there exists bidirectional causality among GDP at $2^{\text {nd }}$ lag and deposit at $3^{\text {rd }}$ lag. While there exists unidirectional causality running from deposit rate to bank deposit.

Table 6. Vector Error-Correction Model for Four Equations.

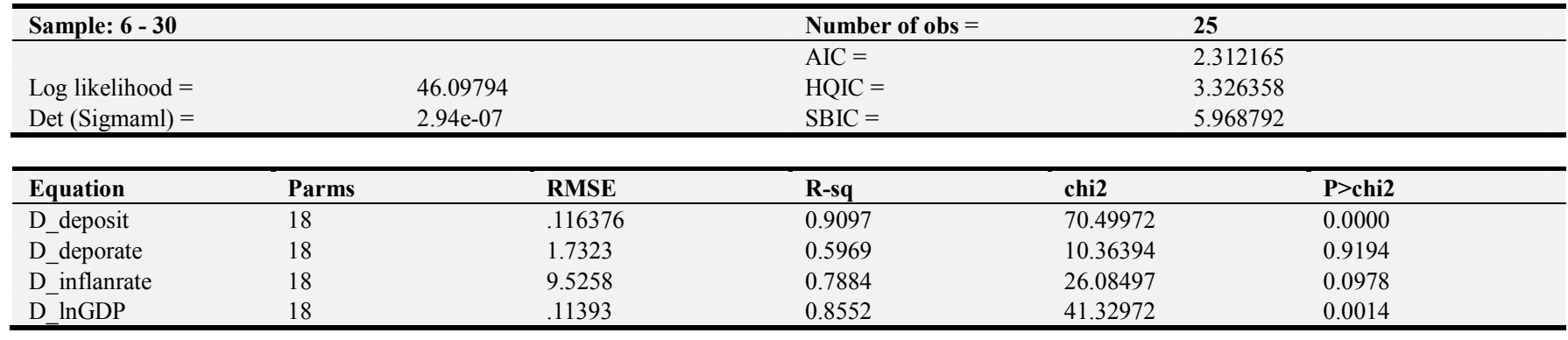

\begin{tabular}{|c|c|c|c|c|}
\hline \multirow{2}{*}{ Short-run causation } & \multicolumn{4}{|l|}{ Equation } \\
\hline & D (InDeposit) (1) & D (inflationR) (2) & D (deporate) (3) & D (InGDP) (4) \\
\hline deposit_LD. & $-.7237127(0.141)$ & $10.0935(0.802)$ & $-2.9690(0.685)$ & $.33820(0.482)$ \\
\hline deposit_L2D. & $-.0546656(0.900)$ & $-2.7187(0.939)$ & $-4.1986(0.519)$ & $.076(0.860)$ \\
\hline deposit_L3D. & $.428353(0.179)$ & $-49.5\left(0.06^{*}\right)$ & $2.383(0.616)$ & $-.5604(0.073 *)$ \\
\hline deposit_L4D. & $.1469852(0.669)$ & $-7.9376(0.778)$ & $.442517(0.931)$ & $.211715(0.530)$ \\
\hline Inflanrate_LD. & $-.0270485\left(0.097^{*}\right)$ & $.035833(0.979)$ & .024633 (0.919) & $.015761(0.323)$ \\
\hline Inflanrate_L2D & $-.0305624\left(0.068^{*}\right)$ & $-.12944(0.925)$ & $-.088303(0.724)$ & $.007596(0.644)$ \\
\hline Inflanrate_L3D & $-.0189932(0.095)$ & $.237443(0.799)$ & $-.002692(0.987)$ & $.009023(0.418)$ \\
\hline Inflanrate_L4D & $-.0107661(0.126)$ & $-.03986(0.945)$ & $-.069334(0.508)$ & $.004641(0.500)$ \\
\hline Deporate_LD. & $.11463(0.007 * * *)$ & $-4.9136(0.156)$ & $.1165171(0.853)$ & $-.056067(0.175)$ \\
\hline Deporate_L2D. & $.085059(0.015 * *)$ & $-.80468(0.778)$ & $.1704979(0.743)$ & $.00884(0.796)$ \\
\hline Deporate_L3D. & $.0113331(0.745)$ & $.8207091(0.77)$ & $.3176906(0.540)$ & $.0024575(0.943)$ \\
\hline Deporate_L4D. & $-.0092137(0.739)$ & $2.467874(0.27)$ & $-.015504(0.970)$ & $.0246468(0.363)$ \\
\hline lnGDP_LD. & $.4412341(0.275)$ & $-14.718(0.656)$ & $-8.25428(0.170)$ & $.359291(0.363)$ \\
\hline
\end{tabular}




\begin{tabular}{lllll}
\hline \multirow{2}{*}{ Short-run causation } & Equation & D (inflationR) (2) & D (deporate) (3) & D (InGDP) (4) \\
\cline { 2 - 5 } & D (InDeposit) (1) & $-5.9789(0.895)$ & $8.261288(0.316)$ & $-.132897(0.806)$ \\
\hline lnGDP_L2D. & $.9507194\left(0.086^{*}\right)$ & $-16.389(0.667)$ & $-2.52023(0.716)$ & $-.402704(0.377)$ \\
lnGDP_L3D. & $.1690467(0.717)$ & $45.7298(0.170)$ & $6.222811(0.305)$ & $.462407(0.246)$ \\
lnGDP_L4D. & $.0908698(0.823)$ & $-2.152231(0.710)$ & $-0.334512(0.751)$ & $-0.0578816(0.404)$ \\
Long-run ECT(-1) & $-0.1572471\left(0.026^{* *}\right)$ & &
\end{tabular}

Note: Probability values are in parenthesis and the rest are coefficients

$* * *, * *$ and $*$ indicates 1percent, 5percent and 10percent level of significance respectively.

Source: Stata 14 output from annual data set, 2018.

The table above also shows that a unidirectional causality running from the third lag of logarithm of deposit to logarithm of GDP. The result confirms the theory that an increase in inflation rate causes tightening of the monetary policy, which increases the risk-free deposit in banks, this in turn causes a shift from investments in different economic sectors to the safer and less risky savings in a bank. In addition, according to Table 4, 6, there exists bidirectional causality among inflation rate at $1^{\text {st }}$ and $2^{\text {nd }}$ lag and deposit at $3^{\text {rd }}$ lag. Similarly, there exists bidirectional causality among GDP at $2^{\text {nd }}$ lag and deposit at $3^{\text {rd }}$ lag. While there exists unidirectional causality running from deposit rate to bank deposit.

Moreover, I conducted joint effect of the lagged values of each explanatory variable on the deposit amount of CBE to show whether there exists a short-run joint effect of the lag of the variables. Since our target variable is the deposit amount of CBE, I examined the joint effects of lags to show the existence of a short-run causality running from other variables to deposit. Thus, according to the table below: the finding indicates that except deposit rate all included variables have no short-run effect on deposit amount. Since the $\mathrm{p}$-value of our test statistics for deposit rate is around 0.0428 which is less than 5percent, we reject the null hypothesis and conclude that there exists a short-run causation running from deposit rate to deposit amount of CBE. Since the p-values for the lags of inflation rate, GDP and deposit are greater than 5 percent level of significance we accept the null hypothesis (Table 7), the coefficients are not significantly different from zero.

Table 7. Short-run joint effect of the lags of each variable on deposit.

H: $_{0}$ LD.deporate $=$ L2D.deporate $=$ L3D.deporate $=$ L4D.deporate $=0$ $\operatorname{chi} 2(4)=9.86$

Prob $>$ chi $2=0.0428$
H $_{0}$ LD.deporate $=$ L2D.deporate $=$ L3D.deporate $=$ L4D.deporate $=0$

$\mathrm{H}_{0}$ : LD.inflanrate $=\mathrm{L} 2 \mathrm{D}$. inflanrate $=\mathrm{L} 3 \mathrm{D}$. inflanrate $=\mathrm{L} 4 \mathrm{D}$. inflanrate $=0$ $\operatorname{chi} 2(4)=3.46$

Prob $>$ chi $2=0.4842$

$\mathrm{H}_{0} \cdot \mathrm{LD} \cdot \operatorname{lnGDP}=\mathrm{L} 2 \mathrm{D} \cdot \operatorname{lnGDP}=\mathrm{L} 3 \mathrm{D} \cdot \operatorname{lnGDP}=\mathrm{L} 4 \mathrm{D} \cdot \ln \mathrm{GDP}=0$

$\operatorname{chi} 2(4)=6.08$

Prob $>$ chi $2=0.1932$

$\mathrm{H}_{0}$ : LD.deposit $=$ L2D.deposit $=$ L3D.deposit $=$ L4D.deposit $=0$

$\operatorname{chi} 2(4)=3.37$

Prob $>$ chi $2=0.4974$

Source: Stata 14 output from annual data set, 2018

The result of Johansen normalization restriction in the next page in Table 4, 8 shows the long-run effect of other variables on deposit amount of CBE. The sign of the coefficients is reversed in the long-run. Keeping other factors remain constant, inflation rate and GDP have a negative effect on deposit, while deposit rate has a positive effect on the total amount of deposit held CBE. More specifically, in the long-run on average as deposit rate increases by a percent, we expect approximately 42 percent increment in the deposit amount, citrus paribus. This might be due to the fact that economic agents are rational as of their positive expectation from long term return from their deposit. This finding is identical to the study in the Kenyan commercial bank deposit growth study [20]. Similarly, in the long-run on average, when GDP increases by a percent, deposit amount will decline by 93 percent, keeping other factors remain constant. Whereas, in the long-run on average an increase of inflation rate by a percent results a 15 percent decline in the total amount of deposit, keeping the effect of others remain constant (Table 8). This is due to the fact that economic agents as a whole are taking their money out of banks to cover their higher expenses at inflationary periods. This finding is consistent with the following findings [22, 24, 25].

Table 8. Johansen normalization restriction for long-run dynamics.

\begin{tabular}{llllll}
\hline beta & Coef. & Std. Err. & $\mathbf{z}$ & P>z & [95percent Conf. \\
\hline ce1 & & & & & \\
deposit & 1 &. &. &. &. \\
deporate & -.417954 & .0136487 & 30.62 & 0.000 & .391203 \\
inflanrate & .1532944 & .0055234 & -27.75 & 0.000 & -.16412 \\
lnGDP & .9313516 & .0566879 & 16.43 & 0.000 & .8202454 \\
cons & -30.18998 &. &. &. & .444705 \\
\hline
\end{tabular}

Source: Stata 14 output from annual data set, 2018

\subsection{Diagnostic Checks Analysis}

To check the validity of our models, we conducted different diagnostic checks that includes Lagrange-multiplier (LM) test for serial correlation of the error term, Jarque-Bera test for normality and the stability test for misspecifications. The result 
in Table 4, 9 indicates that we are accepting the null hypothesis that states there is no auto-correlation problem due to the p-value is greater than 5 percent level of significance. And similarly, since the p-values in the normality test are greater than 5 percent, indicating that we accept the null hypothesis of normally distributed error term. The diagnostics tests indicate the considered model to be well specified.

Table 9. LM test for serial correlation, and Jarque-Bera test for normality.

\begin{tabular}{llll}
\hline \multicolumn{4}{l}{ Lagrange-multiplier test for serial correlation of the error term } \\
\hline \multicolumn{4}{c}{$\mathbf{H}_{\mathbf{0}}: \mathbf{n o}$ autocorrelation at lag order } \\
\hline lag & chi2 & df & Prob $>$ chi2 \\
1 & 38.3437 & 49 & 0.86378 \\
2 & 37.6263 & 49 & 0.88168 \\
\hline
\end{tabular}

\begin{tabular}{llll}
\hline \multicolumn{4}{l}{ Jarque-Bera test for normality } \\
& \multicolumn{3}{l}{$\mathbf{H}_{\mathbf{0}}$ : Residuals are normally distributed } \\
\hline Equation & chi2 & $\mathrm{df}$ & Prob $>$ chi2 \\
D_ddeposit & 5.815 & 2 & 0.05462 \\
D_inflanrate & 0.298 & 2 & 0.86172 \\
D_ddeporate & 1.499 & 2 & 0.47261 \\
D_ddlnGDP & 1.856 & 2 & 0.39532 \\
ALL & 9.468 & 8 & 0.31142 \\
\hline
\end{tabular}

Source: Stata 14 output from annual data set, 2018

Parameter stability test result is shown below in Figure 2 which plots the eigenvalues of the companion matrix with the real component on the $\mathrm{x}$ axis and the imaginary component on the $y$ axis. The figure also displays the stability of our specified model as of the units are within the circle.

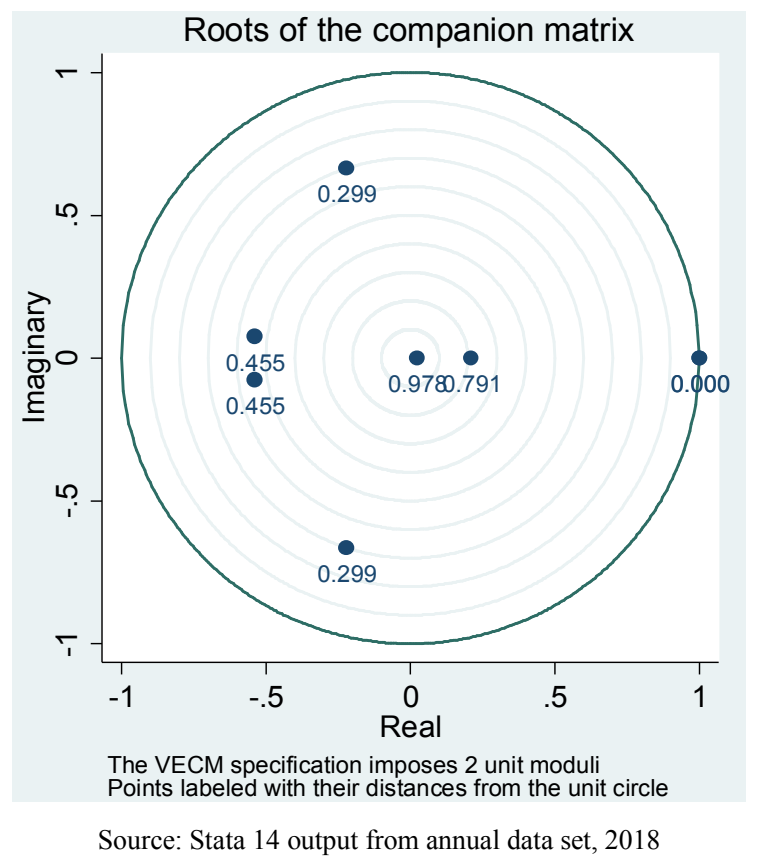

Figure 2. Stability Test Output.

\section{Conclusions and Recommendations}

\subsection{Conclusions}

This study examined the long-run and short run dynamic effects of deposit rate, inflation rate and GDP on bank deposit. Different post-estimation tests and diagnostic tests were conducted to examine the economic series of our variables. To examine their relationships Error Correction Model was employed and accordingly there exists a long-run causality running from deposit rate, interest rate, and GDP to $\mathrm{CBE}$ deposit amount. The finding shows that there is a short-run unidirectional causality running from the first and second lag of inflation rate and deposit rate, and second lag of logarithm of GDP to total amount of deposit held by CBE. Our study also shows that there is a short-run unidirectional causality running from the third lag of logarithm of deposit to inflation rate. In addition, there exists a short-run unidirectional causality running from the third lag of logarithm of deposit to logarithm of GDP.

In addition, there exists bidirectional causality among inflation rate and deposit. Similarly, there exists bidirectional causality among GDP and deposit. While there exists unidirectional causality running from deposit rate to bank deposit. Moreover, we conducted joint effect of the lagged values of each explanatory variable on the deposit amount of CBE to show whether there exists a short-run joint effect of the lag of the variables. The joint effect result indicates that except deposit rate all included variables have no significant short-run effect on deposit amount. More specifically, the result of Johansen normalization restriction shows in the long-run on average inflation rate and GDP have a negative effect on deposit, while deposit rate has a positive effect on the total amount of deposit held by CBE.

\subsection{Recommendations}

According to the findings of this study the following major recommendations are forwarded:

1) The concerned body specially the national bank of Ethiopia should reconsider the minimum amount of deposit (saving) rate as of indicated in our finding deposit rate can play a pivotal role in bank deposit amount.

2) The concerned bodies like national bank of Ethiopia and the government should stabilize the general price index via different policy tools and there by enhance bank deposit.

3) The government, national bank of Ethiopia and other concerned bodies should take necessary steps to mobilize deposit in CBE specifically and in all other banks generally.

4) The researcher recommends others to conduct in related topic by increasing the time frame and including other macroeconomic factors that affect deposit amount of CBE.

\section{Acknowledgements}

At First, may all the honour and glory be extended to the exalted Heavenly God for his help and guidance and encouragement in all over my life.

I am very grateful to my instructors, specially Dr. 
Zerayehu Sime, at post graduate level for what they have shared me their experiences about their skills in conducting an independent research. In addition, I provide sincerely thanks to my wife, Lelise Bacha and my daughter, Kalkidan, for their affection in my life. Further I thank Arba Minch University for providing valuable capacity to prepare this research as a part of fulfilling the seminar work in my $\mathrm{PhD}$ courses. And, Last but not least, I thank very much National bank of Ethiopia, CBE, Central statistical authority and Ministry of finance and economic development for their openness provision of data and annual reports.

\section{References}

[1] National Bank of Ethiopia (2017). Annual Report NBE 2013/14.

[2] Dereje Hailemariam Amene (2017). Determinants of Deposit in Ethiopian Private Commercial Banks, Addis Ababa University.

[3] International Monetary Fund (2016). World Report.

[4] Zerayesus seme, Kagnew Woldie and Teshome Ketama (2013) Competition In Ethiopian Banking Industry, African Journal of Economics, Vol. 1 No. 5.

[5] Mohammad, N., and Mahdi, S. (2010). The Role of Inflation in Financial Repression: Evidence from Iran World Applied Sciences Journal, 6 (1818-4952), 653-661.

[6] Word Bank Group, (2011). SME Finance in Ethiopia: addressing the missing middle challenge 94365 .

[7] Abay (2010) "Domestic Resource Mobilization in Sub-Saharan Africa" The Case of Ethiopia by, University of Addis Ababa, Ethiopia.

[8] Franklin A., Otchere I., and Senbet L. (2011). African financial system: a review: a Review of Development Finance, Vol. 1 No. 2, 79-113.

[9] Mahdi Salehi (2008). 'Corporate Governance and Audit Independence: Empirical Evidence of Iranian Banks' International Journal of Business Management, Vol. 3 No. 12, 44-51.

[10] Kelvin A. (2001). The Role Of Commercial Banks In Financing Growth And Economic Development In Trinidad And Tobago And The Caribbeans: a perspective from the Royal bank of Trinidad and Tobago, central bank of Belize.

[11] HIBRET B. (2015). Determinate of commercial Bank's deposit growth in Ethiopia: case study on the commercial Bank, Addis Ababa University, retrieved from http://etd.aau.edu.et/bitstream/handle/123456789/13540/Hibre $\mathrm{t} \% 20$ Belay $\% 20$.pdf? sequence $=1$ \&isAllowed $=\mathrm{y}$.
[12] Alemayehu G. (2015).'Will the Government of Ethiopia's policy of saving mobilization be successful? The lesson from the African Evidence. Mudaye Neway, Vol. 5 No. 2.

[13] Wubetu Elias Gemedu (2012). Factors Determining Commercial Bank Deposit: An Empirical Study on Commercial Bank of Ethiopia, Addis Ababa University.

[14] Tizita Gebeyehu Yismaw (2014), Determinants of Private Saving In Ethiopia, Maters Theses Arbaminch University.

[15] Andinet (2016). Factors determining deposit mobilization performance: In the case of private commercial banks in Ethiopia (unpublished master's thesis). Addis Ababa University, Addis Ababa.

[16] GIRAGN, G. (2015). Determinants of Deposit Mobilization and Related Costs of Commercial Banks in Ethiopia, Addis Ababa University.

[17] Shemsu B. (2015). Determinants Of Commercial Bank Deposits In Ethiopia: a case of Commercial Bank of Ethiopia, Addis Ababa University.

[18] Engle R. F. and Granger C. W. J. (1987). Econometrica, Vol. 55 No. 2., 251-276.

[19] M. Friedman and Michael Woodford (2011). "The Optimal Rate of Inflation," in Handbook of Monetary Economics edited by Benjamin, Elsevier, San Diego CA, Vol. 3, No. B, 653-722.

[20] Lomuto, J. K. (2008). Determinants of Kenyan Commercial Banks Deposit Growth. University of Nairobi, retrieved from http://erepository.uonbi.ac.ke/bitstream/handle/11295/17109/Lo muto $\% 20 J$ Joel $\% 20 \mathrm{~K}$ Determinants $\% 20 \mathrm{of} \% 20$ Kenyan $\% 20 \mathrm{Com}$ mercial\%20Banks\%20Deposits\%20Growth.pdf?sequence=3.

[21] Nathanael E. O (2014). Determinants of Bank Deposits in Nigeria Under Constraints of Portfolio Selection, being the text of a conference paper presented in the Nigerian Sociological Society Conference at the Delta State University, Abraka.

[22] Otu Larbi-Siaw and Peter Angmor Lawer (2015). Determinants of Bank Deposits in Ghana: A Cointegration Approcah. Asian Journal of Economics and Empirical Research, 2 (2409-2622), 1-7.

[23] M. Friedman and Michael Woodford (2011). "The Optimal Rate of Inflation," in Handbook of Monetary Economics edited by Benjamin, Volume 3B, Elsevier, San Diego CA, 2011, 653-722.

[24] Muhammad, F. M., and Amir, R. (2013). Commercial Banks Liquidity in Pakistan: Firm Specific and Macroeconomic Factors. Romanian Economic Journal, retrieved from $\mathrm{http} / / / w w w . r e j o u r n a l . e u /$ sites/rejournal.versatech.ro/files/artic ole/2013-06.

[25] Athukorala, P.-C. and T. Long Pang (2003). Determinants of household saving in Taiwan: Growth, demography and public policy, Journal of Development Studies, Vol. 39 No. 5, 65-88. 